\title{
EFEK MEDIASI PERUSAHAAN PADA KONSEP MODERATING VARIABEL DAN KONTIGENSI TEORY
}

\author{
Nama \\ POPY AMALIA PAVITRA \\ E-Mail \\ s130119040@student.ubaya.ac.id
}

Teori kontigensi merupakan merupakan sebuah teori yang guna untuk memahami keseimbangan serta keselarasan atau keterkaitan pada hubungan perusahaan dengan lingkungan bisnis internal dan eksternal (Homburg et al., 2012). Pada pengaruh moderating variabel pada sebuah model ini tentunya mengefektifkan baik pembaca maupun penulis untuk mengerti apa yang di maksud melalui bagan yang ada yaitu dengan mengolah kerja otak kita. Dengan kata lain moderating variabel ini ada tujuan lain yaitu dengan memperkuat atau memperlemah hubungan antara satu variabel dengan variabel lainnya yang sesuai dengan analisa (Pratono 2016). Sebagai pembanding, selalu mempergunakan metode model persamaan mediasi pada pembuktian presepsi kualitas lingkungan pada hubungan antara internet dengan kepuasan hiup. Juga dengan memanfaatkan sebuah hasil table berisikan beberpa kumpulan variable dan sampel guna mengetahui letak profit (Binder et al 2020). Model efek mediasi ini dibantu dengan metode Seemingly Unrelated Regression SUR atau sebuah regresi tidak terkait pada pengidentifikasian model efek mediasi menjadi system yang membantu pengefesiensian model yang relevan (Zheng 2019). yang dengan itu di waktu sang mediator kualitas lingkungan ini di masukan dalam regresi hasil sebuah kepuasan pada sang predictor internet usage, namun untuk itu faktor individu tidak dapat di observasi tersebut (Gatignoon 2014).

Teknologi tubelance ini merupakan sebuah hal yang mempengaruhi atau independen variabel dan bisa dalam variabel di pengaruhi yang berarti dependen variabel. TT yang termasuk independen variabel ini yaitu pada pengaruh TT terhadap strategi orientation dan hal-hal tersebut tentu sangat mempengaruhi atau dependen variabel terhadap firm performance atau kinerja suatu perusahaan perusahaan. Hal ini menunjukan bahwasanya TT yang sangat berperan aktif dari segala pandangan yang paling signifikan pada orientasi pasar proaktif. (Pratono 2016). hal kepengaruhan TT atau Technology Turbelance ini bisa dilihat pada grafik yang menunjukan suatu kondisi risk taking behavior yang menunjukan kepengaruhan tersebut yaitu untuk high TT risk taking behavior yang berpengaruh negative pada segala moderating variabel . begitu pula pada keterkaitan dengan penggunaan metode moderating variabel yang mengenai low TT risk taking behavior ini sangat berpengaruh cenderung lebih pada sebaliknya yaitu positif. Pada pengaruh moderating variabel 
pada sebuah model ini tentunya mengefektifkan baik pembaca maupun penulis untuk mengerti apa yang di maksud melalui bagan yang ada yaitu dengan mengolah kerja otak kita. Dengan kata lain moderating variabel ini ada tujuan lain yaitu dengan memperkuat atau memperlemah hubungan antara satu variabel dengan variabel lainnya, yaitu pada hakikatnya suatu TT atau Technology Turbalance ini memperkuat pengaruh antara Strategy Orientation (strategi orientasi) pada Firm Performance (kinerja perusahaan). Yang artinya ini adalah strategi orientasi ini berpengaruh pada kinerja perusahaan, dan terdapatnya TT dengan tingkatan tinggi ini maka pengaruh antara strategi orientasi dengan kinerja perusahaan ini lebih meningkat

Selanjutnya untuk jurnal (1) ini menyatakan sebuah Big Data yang memainkan peran yang semakin penting dalam proses pengambilan keputusan dan operasi. Begitu pula dengan hubungan antara CSR (Corporate Sosial Responsibility) dan GSCM (Green Supply Chain Management) dengan moderating variabelnya dari sebuah kapabilitas analitik Big Data dalam proses pembentukan sebuah GSCM. sehingga bisa dikatakan sebagai tingkat CSR baik internal maupun eksternal ini berpengaruh positif terhadap GSCM, lalu GSCM ini sangat berdampak positif pada sebuah Firm Performance atau kinerja perusahaan tersebut

Pada jurnal (A, H Pratono 2018) ini menyatakan bahwasanya terdapatnya hubungan positif antara proaktif pekerja dan perilaku inovativ (Pak \& Jo, 2018). Secara signifikan informasi motivasi proaktif berhubungan positif dengan kinerja operasional perusahaan melalui inovasi terbuka. Hal tersebut sangatlah independen pada dua sisi formal. Dimana hubungan positif yang terjalin antara IPM atau Information Proactivness Motivation dan Inovasi terbuka lebih kuat atau lebih positif dengan tingkat kreatifitas kogntif yang tinggi dibandingkan tingkat kreatifitas kognitif yang rendah, adapun pandangan lain yang mengatakan bahwa sebuah interaksi inovasi terbuka dan iklim inovasi signifikan untuk kinerja operasional perusahaan. Dan bootstrapping result ini mengotentasikan bahwasannya inovasi terbuka ini memiliki efek langsung bersyarat Firm Performance atau kinerja perusahaan operasional.

Pada jurnal (A.H. Pratono 2019) dengan sebuah model mediator ini menunjukan sebuah pengaruh pada sebuah varibel dependen dan independen pada penggerak baik antar organisasi hingga orientasi pasar yaitu dibuktikan dengan adanya hubungan kompleks yang menjadikan sebuah proses transformasi dari Green Entreprenuerial Orientation (GEO) atau Entrepreneur Orientasi Hijau menjadi keunggulan, namun untuk itu juga telah di bukikan dengan pembuktian 
pada model deiasi ini yaitu pada hipothesis yang terbukti dengan menunjukan hasil pada metode mediasi tersebut yang memberikan efek pada tingkatan besaran yang mempengaruhi faktor-faktor penentu dengan entrepreneur orientation ini memiliki nilai yang lebih tinggi. Dengan begitu metode dengan model mediasi ini sangat berpengaruh pada hasil hypothesis yang akan kita ketahui dengan pemahaman variabel independen dan dependen juga dengan pengujian beberapa sampel pada pengujian pada hubungan yang kompleks antara GEO, orientasi pasar dan daya saing untuk keuntungan yang berkelanjutan. Sedangkan Pada jurnal (A. H. Pratono 2018) ini sebuah studi melalui variabel mediasi yang kuat pada proses penting yaitu hubungan posistif pada perubahan social network atau jejaring sosial menjadi firm performance atau sebuah kinerja perusahaan akan membantu dalam mendapatkan sebuah keuntungan pada penetapan harga capabilitas dengan pemanfaatan media sosial berbasis kepercayaan pada kompleksitas ini. 


\section{DAFTAR PUSTAKA}

Naseer, S. K. (2021). How and When Information Proactiveness Leads to Operational Firm Performance in The Banking Sector of Pakistan? The Roles of Open. International Journal of Information Management, Vol 56 (102-260).

Pratono, A. (2019). Achieving Sustainable Competitive Advantage through Green. The role of inter-organizational, , vol 32, 2-15.

Pratono, A. H. (2016). Strategic Orientation and Information Technological Turbulence :Contigency Prepektive in SMEs. Business Process Management Journal, vol 22(2), 368382.

Pratono, A. H. (2018). Does Entrepreneurial Autonomy Foster SME Growth Under Technological Turbulence? The Empirical Evidence from Indonesia. Journal of Technological Behaviour Science, Vol 3, (170-178).

Pratono, A. H. (2018). Does Firm Performance Incrase with Risk-Taking Behavior Under Information Technological Turbulence? : Empiricial Evidence from Indonesia SMEs. The Journal of Risk Finance, vol19(4), 361-378.

Pratono, A. H. (2018). From Social Network to Firm Performance: The Mediating Effect of Trust,. Management Research Review, vol 41, 680-700.

Wang, C. Z. (Pre print 1). Corporate Social Responsibility, Green Supply Chain Management and Firm Performance: The Moderating Role of Big-Data Analytics Capability. Research in Transportation Business \& Management.

Zhang, J. C. (2020). Internet Use and Lower Life Satisfaction: The Mediating. Ecological Economics, vol 176, 106-725. 